\title{
Article \\ A Novel Cytotoxic Steroidal Saponin from the Roots of Asparagus cochinchinensis
}

\author{
Ji-Young Kim ${ }^{1,+}{ }^{+}$, He Yun Choi ${ }^{2,+}$, Hye Mi Kim ${ }^{3}$, Jung-Hye Choi ${ }^{1,2,3, *}$ and Dae Sik Jang ${ }^{1,2,3, *(\mathbb{D})}$ \\ 1 Department of Biomedical and Pharmaceutical Sciences, Graduate School, Kyung Hee University, \\ Seoul 02447, Korea; k_christina@khu.ac.kr \\ 2 Department of Life and Nanopharmaceutical Sciences, Graduate School, Kyung Hee University, \\ Seoul 02447, Korea; choiheyun@khu.ac.kr \\ 3 College of Pharmacy, Kyung Hee University, Seoul 02447, Korea; hyemi586@gmail.com \\ * Correspondence: jchoi@khu.ac.kr (J.-H.C.); dsjang@khu.ac.kr (D.S.J) \\ + These authors contributed equally to this work and joint first authors.
}

check for updates

Citation: Kim, J.-Y.; Choi, H.Y.; Kim, H.M.; Choi, J.-H.; Jang, D.S. A Novel Cytotoxic Steroidal Saponin from the Roots of Asparagus cochinchinensis. Plants 2021, 10, 2067. https:// doi.org/10.3390/plants10102067

Academic Editors: Marcello Iriti and Sara Vitalini

Received: 14 September 2021

Accepted: 29 September 2021

Published: 30 September 2021

Publisher's Note: MDPI stays neutral with regard to jurisdictional claims in published maps and institutional affiliations.

Copyright: (c) 2021 by the authors. Licensee MDPI, Basel, Switzerland. This article is an open access article distributed under the terms and conditions of the Creative Commons Attribution (CC BY) license (https:// creativecommons.org/licenses/by/ $4.0 /)$.
Abstract: A new steroidal saponin, 26-O- $\beta$-D-glucopyranosyl-(25R)-furost-5-ene-3 $\beta, 22 \alpha, 26-$ triol 3-O(1-4)- $\beta$-D-glucopyranosyl- $\alpha$-L-rhamnopyranosyl-(1-2)-[ $\alpha$-L-rhamnopyranosyl-(1-4)]- $\beta$-D-glucopyranoside [asparacochioside A (1)] was isolated from a hot water extract of the roots of Asparagus cochinchinensis, together with the known steroidal saponins protodioscin (2), methyl protodioscin (3), aspacochioside A (4), aspacochioside C (5), 15-hydroxypseudoprotodioscin (6), and chamaedroside $\mathrm{E}$ (7). The structure of the new compound 1 was determined by interpretation of its spectroscopic data (1D- and 2D-NMR and HR-Q-TOF-MS) and sugar analysis. The isolated compounds 1-7 were tested for their in vitro cytotoxicity against human ovarian cancer cell lines (A2780 and SKOV3). Asparacochioside A (1) exhibited a significant cytotoxicity against both A2780 and SKOV3 cells with IC50 values of $5.25 \pm 2.2$ and $46.82 \pm 9.43 \mu \mathrm{M}$, respectively. Furthermore, asparacochioside A (1) significantly increased the percentage of Annexin V-positive cells (apoptotic cells), suggesting that asparacochioside A induces ovarian cancer cell death via apoptosis.

Keywords: Asparagus cochinchinensis; cytotoxicity; Liliaceae; ovarian cancer cells; steroidal saponin

\section{Introduction}

The genus Asparagus (Liliaceae) comprises over three hundred species distributed around the world and used in salads and as herbs and vegetables. Asparagus cochinchinensis (Loureio) Merrill is a perennial herb distributed in Eastern Asia, including many provinces of China, Japan, and Korea [1]. The dried roots of $A$. cochinchinensis have been used in Traditional Chinese Medicine for more than two thousand years to treat fevers, renal failure, heart diseases, and lung cancer [2].

Moreover, extensive chemical studies on the roots of $A$. cochinchinensis have led to the identification of many compounds, such as steroidal saponins, mono-, oligo-, and polysaccharides, and amino acids [3,4]. The extracts of $A$. cochinchinensis and the corresponding constituents have been shown to have several pharmacological effects, including anti-oxidant [5] and anti-inflammatory effects [6]. Additionally, cytotoxicity against several human cancer cell lines such as cervical cancer HeLa, lung cancer NCI-H460, breast cancer MCF-7, and liver cancer HepG2 cells has been reported [5,7]. Steroidal saponins from $A$. cochinchinensis and other plants such as Smilax davidiana and Polygonautm sibiricum are also known to have anti-inflammatory effects by inhibiting cytokine production and cytotoxicity against tumor cell lines $[8,9]$.

In our continuing search for bioactive compounds from medicinal plants, the roots of A. cochinchinensis were chosen for a phytochemical investigation, since its hot water extract was found to have significant cytotoxicity against human ovarian carcinoma (A2780) and 
human female ovarian adenocarcinoma (SKOV3) cell lines with 30 and 39\% cell growth inhibition at $200 \mu \mathrm{g} / \mathrm{mL}$, respectively.

In the present study one new (compound $\mathbf{1}$ ) and six known steroidal saponins 2-7 were purified from the roots of $A$. cochinchinensis by repeated chromatography. The structure of the new compound 1 was elucidated by interpreting 1D- and 2D-nuclear magnetic resonance (NMR) spectroscopic data analysis, acid hydrolysis, and high-resolution quadrupole time of flight mass $(\mathrm{HR}-\mathrm{Q}-\mathrm{TOF}-\mathrm{MS})$ spectrometric data analysis. All the isolated compounds 1-7 were evaluated for their cytotoxicity against ovarian cancer cell lines (A2780 and SKOV3). To summarize, in this paper, we describe the isolation of steroidal saponins 1-7 from the roots of $A$. cochinchinensis, structure elucidation of the new steroidal saponin $\mathbf{1}$, and cytotoxicity of the isolates against human ovarian cancer cells.

\section{Results and Discussion}

\subsection{Structure Elucidation of Compound $\mathbf{1}$}

One new (compound $\mathbf{1}$ ) and six known furostane-type steroidal saponins 2-7 were isolated from the roots of $A$. cochinchinensis (Figure 1).
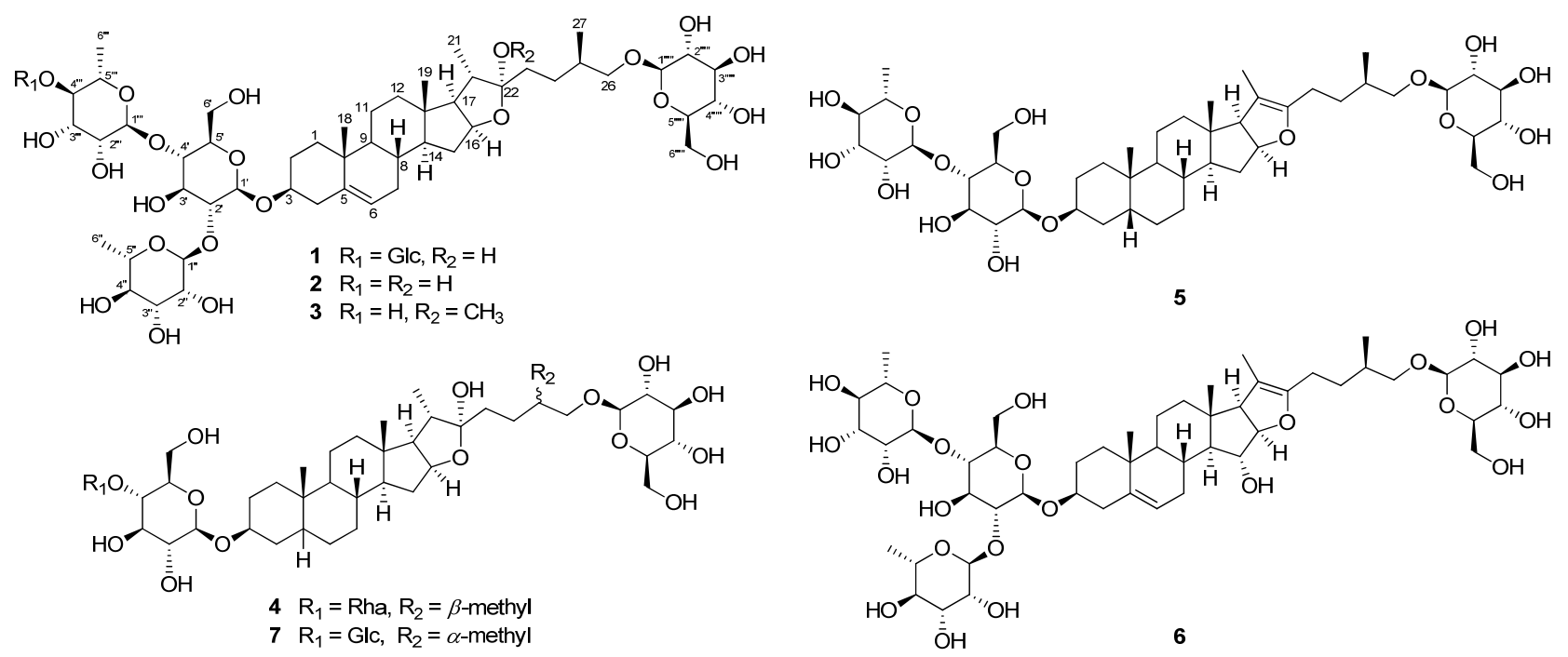

Figure 1. Structures of compounds 1-7 isolated from the roots of A. cochinchiensis.

Compound 1 was isolated as a pale brown powder. The molecular formula was established as $\mathrm{C}_{57} \mathrm{H}_{94} \mathrm{O}_{27}$ through $\mathrm{HR}-\mathrm{Q}-\mathrm{TOF}-\mathrm{MS}$ isotopic ion peaks at $m / z=1209.5892$ $[\mathrm{M}-\mathrm{H}]^{-}$(calcd for $\left.\mathrm{C}_{57} \mathrm{H}_{93} \mathrm{O}_{27}, 1209.5904\right)$ (Figure S1). The ${ }^{1} \mathrm{H}-\mathrm{NMR}$ spectrum of $\mathbf{1}$ exhibited six methyl signals at $\delta_{\mathrm{H}} 0.89(3 \mathrm{H}, \mathrm{s}), 0.99(3 \mathrm{H}, \mathrm{d}, J=6.5 \mathrm{~Hz}), 1.08(3 \mathrm{H}, \mathrm{s}), 1.34(3 \mathrm{H}$, $\mathrm{d}, J=7.0 \mathrm{~Hz}), 1.67(3 \mathrm{H}, \mathrm{d}, J=6.0 \mathrm{~Hz}), 1.77(3 \mathrm{H}, \mathrm{d}, J=6.0 \mathrm{~Hz})$, and five anomeric protons at $\delta_{\mathrm{H}} 4.81(1 \mathrm{H}, \mathrm{d}, J=7.5 \mathrm{~Hz}), 4.95(1 \mathrm{H}, \mathrm{d}, J=7.5 \mathrm{~Hz}), 5.24(1 \mathrm{H}, \mathrm{d}, J=7.5 \mathrm{~Hz}), 5.87(1 \mathrm{H}, \mathrm{s})$, and $6.42(1 \mathrm{H}, \mathrm{s})$ (Table 1, Figure S2) [10]. The ${ }^{13} \mathrm{C}-\mathrm{NMR}$, distoriionless enhancement by polarization transfer (DEPT)135-NMR, and ${ }^{1} \mathrm{H}_{-}{ }^{13} \mathrm{C}$ heteronuclear single quantum coherence spectroscopy (HSQC) spectra showed 57 signals with six methyl signals at $\delta_{\mathrm{C}} 16.4 \times 2,17.4$, $18.3,18.6$, and 19.3, 13 methylene carbon signals at $\delta_{\mathrm{C}} 21.0,28.3,30.1,32.2,32.4,37.1,37.4$, $38.9,39.8,78.5,61.1,62.3$, and 62.7 , nine methine carbons in aglycone moiety including an olefinic carbon at $\delta_{\mathrm{C}} 31.6,34.2,40.6,50.3,56.6,63.7,78.0,81.0$, and 121.8, and four quaternary carbons at $\delta_{\mathrm{C}} 37.1,40.7,110.6$, and 140.7 (Table 1, Figures S3 and S4). According to the ${ }^{1} \mathrm{H}$ - and ${ }^{13} \mathrm{C}-\mathrm{NMR}$ and HSQC data, compound 1 could be expected to have five sugars $\left[\delta_{\mathrm{C}} / \delta_{\mathrm{H}} 100.3 / 4.95,1 \mathrm{H}, \mathrm{d}(7.5) ; 102.0 / 5.88,1 \mathrm{H}, \mathrm{s} ; 101.9 / 6.42,1 \mathrm{H}, \mathrm{s} ; 106.7 / 5.24,1 \mathrm{H}\right.$, $\mathrm{d}(7.5) ; 104.8 / 4.81,1 \mathrm{H}, \mathrm{d}(7.5)]$. Based on the ${ }^{1} \mathrm{H}^{-1} \mathrm{H}$ correlation spectroscopy (COSY) and ${ }^{1} \mathrm{H}_{-}{ }^{13} \mathrm{C}$ heteronuclear multiple bond correlation (HMBC) data (Figures S5 and S6), it was inferred that compound $\mathbf{1}$ is a furostane-type steroidal saponin. 
Table 1. ${ }^{1} \mathrm{H}$ - and ${ }^{13} \mathrm{C}-\mathrm{NMR}$ spectroscopic data for the aglycones of compounds 1 and $2\left(\delta\right.$ in ppm, $\mathrm{C}_{5} \mathrm{D}_{5} \mathrm{~N}, 800$ and $200 \mathrm{MHz}$ ).

\begin{tabular}{|c|c|c|c|c|}
\hline \multirow{2}{*}{ Position } & \multicolumn{2}{|l|}{1} & \multicolumn{2}{|l|}{ Protodioscin (2) ${ }^{a}$} \\
\hline & $\delta_{\mathbf{H}}$ Multi $(J$ in Hz) & $\delta_{\mathrm{C}}$ & $\delta_{\mathrm{H}}$ Multi $(J$ in Hz) & $\delta_{\mathrm{C}}$ \\
\hline 1 & $1.85,1 \mathrm{H}, \mathrm{m} / 2.07,1 \mathrm{H}, \mathrm{m}$ & 30.1 & $1.86,1 \mathrm{H}, \mathrm{m} / 2.08,1 \mathrm{H}, \mathrm{m}$ & 29.8 \\
\hline 2 & $1.44,2 \mathrm{H}, \mathrm{m}$ & 21.0 & $1.54,2 \mathrm{H}, \mathrm{m}$ & 20.9 \\
\hline 3 & $3.88,1 \mathrm{H}, \mathrm{d}(11.0,6.5)$ & 78.0 & $3.81,1 \mathrm{H}^{b}$ & 78.4 \\
\hline 4 & $2.73,1 \mathrm{H}, \mathrm{d}(11.0) / 2.79,1 \mathrm{H}, \mathrm{d}(10.5)$ & 38.9 & $2.74,1 \mathrm{H}, \mathrm{d}(11.5) / 2.79,1 \mathrm{H}, \mathrm{d}(10.5)$ & 38.8 \\
\hline 5 & - & 140.7 & - & 140.6 \\
\hline 6 & $5.30,1 \mathrm{H}, \mathrm{s}$ & 121.8 & $5.34,1 \mathrm{H}, \mathrm{s}$ & 121.8 \\
\hline 7 & $1.88,2 \mathrm{H}, \mathrm{m}$ & 32.2 & $1.86,2 \mathrm{H}, \mathrm{m}$ & 32.2 \\
\hline 8 & $1.57,1 \mathrm{H}, \mathrm{m}$ & 31.6 & $1.56,1 \mathrm{H}, \mathrm{m}$ & 31.5 \\
\hline 9 & $0.90,1 \mathrm{H}^{b}$ & 50.3 & $0.90,1 \mathrm{H}^{b}$ & 50.1 \\
\hline 10 & - & 37.1 & - & 37.1 \\
\hline 11 & $0.98,1 \mathrm{H}^{b} / 1.32,1 \mathrm{H}^{b}$ & 37.4 & $0.97,1 \mathrm{H}^{b} / 1.30,1 \mathrm{H}^{b}$ & 37.8 \\
\hline 12 & $1.12,1 \mathrm{H}, \mathrm{m} / 1.74,1 \mathrm{H}, \mathrm{m}$ & 39.8 & $1.12,1 \mathrm{H}, \mathrm{m} / 1.75,1 \mathrm{H}, \mathrm{m}$ & 39.7 \\
\hline 13 & - & 40.7 & - & 40.6 \\
\hline 14 & $1.07,1 \mathrm{H}^{b}$ & 56.6 & $1.07,1 \mathrm{H}^{b}$ & 56.4 \\
\hline 15 & $1.48,1 \mathrm{H}^{b} / 2.02,1 \mathrm{H}^{b}$ & 32.4 & $1.48,1 \mathrm{H}, \mathrm{m} / 2.03,1 \mathrm{H}, \mathrm{m}$ & 32.3 \\
\hline 16 & $4.96,1 \mathrm{H}, \mathrm{t}(4.5)$ & 81.0 & $4.46,1 \mathrm{H}, \mathrm{m}$ & 81.1 \\
\hline 17 & $1.93,1 \mathrm{H}^{b}$ & 63.7 & $1.94,1 \mathrm{H}^{b}$ & 63.7 \\
\hline 18 & 1.08. $3 \mathrm{H}, \mathrm{s}$ & 19.3 & $1.05,3 \mathrm{H}, \mathrm{s}$ & 19.2 \\
\hline 19 & $0.89,3 \mathrm{H}, \mathrm{s}$ & 16.4 & $0.89,3 \mathrm{H}, \mathrm{s}$ & 16.3 \\
\hline 20 & $2.25,1 \mathrm{H}, \mathrm{q}(2.0)$ & 40.6 & $2.24,1 \mathrm{H}, \mathrm{m}$ & 40.5 \\
\hline 21 & $1.34,3 \mathrm{H}, \mathrm{d}(7.0)$ & 16.4 & $1.34,3 \mathrm{H}, \mathrm{d}(7.0)$ & 16.3 \\
\hline 22 & - & 110.6 & - & 111.0 \\
\hline 23 & $2.07,2 \mathrm{H}^{b}$ & 37.1 & $1.57,2 \mathrm{H}, \mathrm{dd}(10.5,5.0)$ & 30.0 \\
\hline 24 & $1.68,1 \mathrm{H}, \mathrm{d}(4.0) / 2.05,1 \mathrm{H}, \mathrm{m}$ & 28.3 & $1.68,1 \mathrm{H}, \mathrm{d}(4.0) / 2.05,1 \mathrm{H}, \mathrm{m}$ & 28.2 \\
\hline 25 & $1.94,1 \mathrm{H}^{b}$ & 34.2 & $1.96,1 \mathrm{H}^{b}$ & 34.1 \\
\hline 26 & $\begin{array}{c}3.63,1 \mathrm{H}, \mathrm{dd}(9.5,6.0) / 3.95,1 \mathrm{H}, \mathrm{dd} \\
(9.0,6.5)\end{array}$ & 78.5 & $3.63,1 \mathrm{H}, \mathrm{d}(4.0) / 3.99,1 \mathrm{H}, \mathrm{d}(6.5)$ & 78.4 \\
\hline 27 & $0.99,3 \mathrm{H}, \mathrm{d}(6.5)$ & 17.4 & $0.99,3 \mathrm{H}, \mathrm{d}(6.0)$ & 17.3 \\
\hline
\end{tabular}

${ }^{a}$ NMR data of compound 2 isolated in this study. ${ }^{b}$ signal is overlapped.

Through analysis of the HMBC and nuclear Overhauser effect correlation spectroscopy (NOESY) spectra (Figure 2, Figures S6 and S7), it was proposed that compound $\mathbf{1}$ has three glucoses and two rhamnoses [11]. The positions of the sugars were determined by analysis of the HMBC correlations; $\mathrm{H}-\mathrm{Glc}-1^{\prime}$ [ $\delta 4.95(1 \mathrm{H}, \mathrm{d}, J=7.5 \mathrm{~Hz})$ ] with $\mathrm{C}-3$

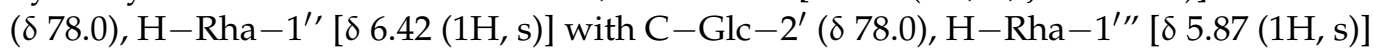
with $\mathrm{C}-\mathrm{Glc}-4^{\prime}(\delta 78.4)$, and $\mathrm{H}-\mathrm{Glc}-1^{\prime \prime \prime \prime \prime}[\delta 5.24(1 \mathrm{H}, \mathrm{d}, J=7.5 \mathrm{~Hz})]$ with $\mathrm{C}-26(\delta 78.5)$ (Figure 2). The glucoses and rhamnoses in compound 1 were identified as $\beta$-D- and $\alpha$-L-forms, respectively, based on the coupling constants of the anomeric protons and acid hydrolysis followed by high performance liquid chromatography (HPLC) analysis. The ${ }^{1} \mathrm{H}$ - and ${ }^{13} \mathrm{C}-\mathrm{NMR}$ spectroscopic data of compound $\mathbf{1}$ were very similar to those of protodioscin (2), except for the presence of an additional $\beta$-glucose unit at Rha- $4^{\prime \prime \prime}$ in 1 (Tables 2 and 3, Figure 1) [10]. The chemical structure of compound 1 was very resemble to costucoside I, isolated from the seeds of Costus speciosus which only differ from the position of Glc-1'"' at Rha- $3^{\prime \prime \prime}$ [12]. The absolute configuration of the methyl group at C-25 was determined as $R$ by the difference in proton NMR chemical shifts between $\mathrm{H}_{2}-26 \alpha$ and $\mathrm{H}_{2}-26 \beta\left(\Delta_{\mathrm{ab}}=0.32\right)[13,14]$. Thus, the chemical structure of the new furostane-type steroidal saponin 1 was elucidated as $26-O-\beta$-D-glucopyranosyl-(25R)furost-5-ene-3 $\beta, 22 \alpha, 26$-triol 3-O-(1-4)- $\beta$-D-glucopyranosyl- $\alpha$-L-rhamnopyranosyl-(1-2)[ $\alpha$-L-rhamnopyranosyl-(1-4)]- $\beta$-D-glucopyranoside and named asparacochioside A. 


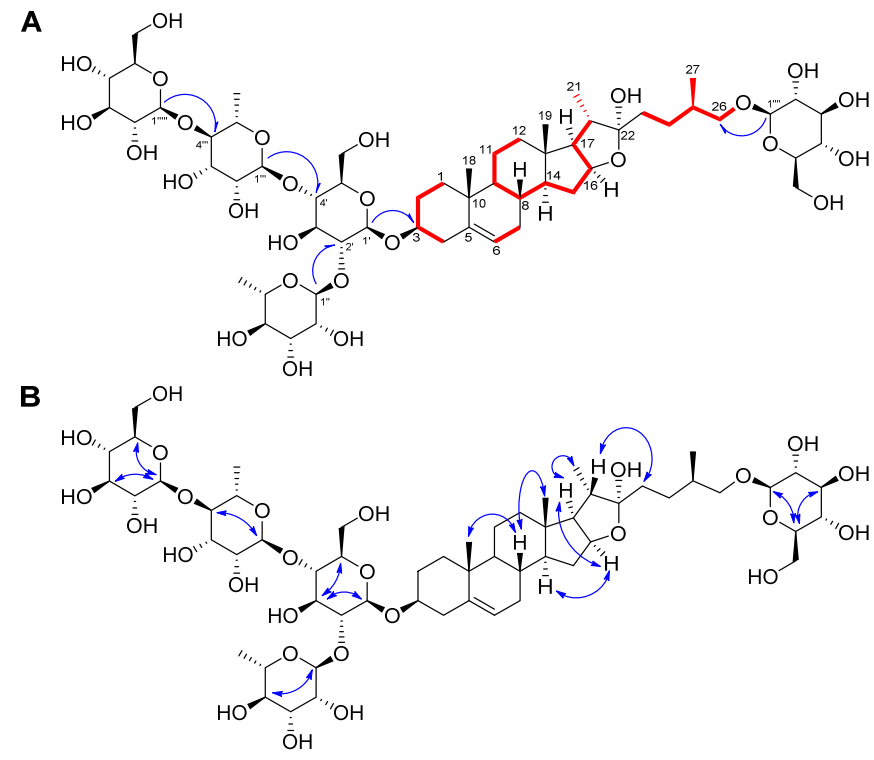

Figure 2. Key ${ }^{1} \mathrm{H}-{ }^{1} \mathrm{H} \operatorname{COSY}(-)$ and $\mathrm{HMBC}(\longrightarrow)$ correlations of compound $\mathbf{1}(\mathrm{A}) \cdot \mathrm{Key}{ }^{1} \mathrm{H}-{ }^{1} \mathrm{H}$ $\operatorname{NOESY}(\neg$ : blue dashed arrows) correlations of compound $\mathbf{1}(\mathrm{B})$.

Table 2. ${ }^{1} \mathrm{H}$ - and ${ }^{13} \mathrm{C}-\mathrm{NMR}$ spectroscopic data for the sugar moieties of compounds $\mathbf{1}$ and $2\left(\delta\right.$ in ppm, $\mathrm{C}_{5} \mathrm{D}_{5} \mathrm{~N}, 800$ and $200 \mathrm{MHz})$.

\begin{tabular}{|c|c|c|c|c|}
\hline \multirow{2}{*}{ Position } & \multicolumn{2}{|l|}{1} & \multicolumn{2}{|c|}{ Protodioscin (2) ${ }^{a}$} \\
\hline & $\delta_{\mathrm{H}}$ Multi $(J$ in $\mathrm{Hz})$ & $\delta_{\mathrm{C}}$ & $\delta_{\mathbf{H}}$ Multi $(J$ in $\mathrm{Hz})$ & $\delta_{\mathrm{C}}$ \\
\hline 3-O-Glc-1' & $4.95,1 \mathrm{H}, \mathrm{d}(7.5)$ & 100.3 & $4.96,1 \mathrm{H}, \mathrm{d}(7.0)$ & 100.1 \\
\hline $2^{\prime}$ & $3.88,1 \mathrm{H}^{b}$ & 78.0 & $3.78,1 \mathrm{H}^{b}$ & 77.9 \\
\hline $3^{\prime}$ & $3.63,1 \mathrm{H}^{b}$ & 76.9 & $3.61,1 \mathrm{H}^{b}$ & 76.8 \\
\hline $4^{\prime}$ & $3.95,1 \mathrm{H}^{b}$ & 78.4 & $3.92,1 \mathrm{H}^{b}$ & 78.3 \\
\hline $5^{\prime}$ & $4.43,1 \mathrm{H}^{b}$ & 77.3 & $4.40,1 \mathrm{H}^{b}$ & 77.5 \\
\hline $6^{\prime}$ & $4.06,1 \mathrm{H}, \mathrm{t}(8.0) / 4.20,1 \mathrm{H}^{b}$ & 61.1 & $4.04,1 \mathrm{H}, \mathrm{t}(8.0) / 4.23,1 \mathrm{H}^{b}$ & 61.1 \\
\hline $2^{\prime}-O-R h a-1^{\prime \prime}$ & $6.42,1 \mathrm{H}, \mathrm{s}$ & 101.9 & $6.41,1 \mathrm{H}, \mathrm{s}$ & 101.9 \\
\hline $2^{\prime \prime}$ & $4.67,1 \mathrm{H}^{b}$ & 71.8 & $4.61,1 \mathrm{H}^{b}$ & 72.4 \\
\hline $3^{\prime \prime}$ & $4.87,1 \mathrm{H}, \mathrm{s}$ & 72.5 & $4.75,1 \mathrm{H}, \mathrm{s}$ & 72.6 \\
\hline $4^{\prime \prime}$ & $4.37,1 \mathrm{H}^{b}$ & 74.00 & $4.34,1 \mathrm{H}^{b}$ & 73.8 \\
\hline $5^{\prime \prime}$ & $5.04,1 \mathrm{H}^{b}$ & 69.5 & $4.95,1 \mathrm{H}^{b}$ & 69.4 \\
\hline $6 "$ & $1.77,3 \mathrm{H}, \mathrm{d}(6.0)$ & 18.3 & $1.76,3 \mathrm{H}, \mathrm{d}(6.0)$ & 18.4 \\
\hline $4^{\prime}-O-R h a-1^{\prime \prime \prime}$ & $5.87,1 \mathrm{H}, \mathrm{s}$ & 102.0 & $5.87,1 \mathrm{H}, \mathrm{s}$ & 102.7 \\
\hline $2^{\prime \prime \prime}$ & $4.64,1 \mathrm{H}, \mathrm{dd}(9.0,3.0)$ & 72.4 & $4.61,1 \mathrm{H}, \mathrm{dd}(9.0,3.0)$ & 72.4 \\
\hline $3^{\prime \prime \prime}$ & $4.65,1 \mathrm{H}, \mathrm{d}(4.5)$ & 72.8 & $4.61,1 \mathrm{H}, \mathrm{m}$ & 72.7 \\
\hline $4^{\prime \prime \prime}$ & $4.21,1 \mathrm{H}^{b}$ & 74.01 & $4.61,1 \mathrm{H}^{b}$ & 73.3 \\
\hline $5^{\prime \prime \prime}$ & $4.96,1 \mathrm{H}^{b}$ & 71.2 & $4.92,1 \mathrm{H}^{b}$ & 70.2 \\
\hline $6^{\prime \prime \prime}$ & $1.67,3 \mathrm{H}, \mathrm{d}(6.0)$ & 18.6 & $1.64,3 \mathrm{H}, \mathrm{d}(6.0)$ & 18.5 \\
\hline 26-O-Glc-1"“" & $4.81,1 \mathrm{H}, \mathrm{d}(7.5)$ & 104.8 & $4.87,1 \mathrm{H}, \mathrm{d}(7.5)$ & 104.8 \\
\hline $2^{\prime \prime \prime \prime}$ & $4.14,1 \mathrm{H}, \mathrm{t}(8.5)$ & 75.1 & $4.14,1 \mathrm{H}, \mathrm{t}(8.5)$ & 75.0 \\
\hline $3^{\prime \prime \prime \prime}$ & $3.84,1 \mathrm{H}^{b}$ & 77.9 & $3.85,1 \mathrm{H}, \mathrm{m}$ & 77.8 \\
\hline $4^{\prime \prime \prime \prime}$ & $4.24,1 \mathrm{H}^{b}$ & 71.6 & $4.23,1 \mathrm{H}^{b}$ & 71.5 \\
\hline $5^{\prime \prime \prime}$ & $4.29,1 \mathrm{H}, \mathrm{t}(9.5)$ & 78.5 & $4.30,1 \mathrm{H}, \mathrm{t}(9.0)$ & 78.4 \\
\hline $6^{\prime \prime \prime}$ & $4.36,1 \mathrm{H}^{b} / 4.40,1 \mathrm{H}^{b}$ & 62.7 & $4.36,1 \mathrm{H}^{b} / 4.41,1 \mathrm{H}^{b}$ & 62.6 \\
\hline $4^{\prime \prime \prime}-\mathrm{O}-\mathrm{Glc}-1^{\prime \prime \prime \prime \prime}$ & $5.24,1 \mathrm{H}, \mathrm{d}(7.5)$ & 106.7 & & \\
\hline $2 " 1$, & $4.03,1 \mathrm{H}, \mathrm{m}$ & 76.5 & & \\
\hline $3^{\prime \prime \prime \prime \prime}$ & $3.63,1 \mathrm{H}, \mathrm{m} / 3.95,1 \mathrm{H}, \mathrm{m}$ & 75.3 & & \\
\hline $4^{\prime \prime \prime \prime \prime}$ & $4.23,1 \mathrm{H}^{b}$ & 78.5 & & \\
\hline $5^{\prime \prime \prime \prime \prime}$ & $4.30,1 \mathrm{H}, \mathrm{t}(9.0)$ & 71.2 & & \\
\hline $6^{\prime \prime \prime \prime \prime}$ & $4.37,1 \mathrm{H}^{b} 4.51 / 1 \mathrm{H}, \mathrm{d}(11.5)$ & 62.3 & & \\
\hline
\end{tabular}

${ }^{a}$ NMR data of compound 2 isolated in this study. ${ }^{b}$ signal is overlapped. 
Table 3. The cytotoxicity of compounds 1-3 isolated from A. cochinchinensis in A2780 and SKOV3 human ovarian cancer cells.

\begin{tabular}{ccc}
\hline \multirow{2}{*}{ Compound } & \multicolumn{2}{c}{$\mathbf{I C}_{\mathbf{5 0}}(\boldsymbol{\mu} \mathbf{M})^{a}$} \\
\cline { 2 - 3 } & $\mathbf{A 2 7 8 0}$ & SKOV3 \\
\hline $\mathbf{1}$ & $5.25 \pm 2.2^{d, e, f}$ & $46.82 \pm 9.43^{f}$ \\
$\mathbf{3}$ & $10.14 \pm 0.12^{c, e}$ & $>100$ \\
Cisplatin $^{b}$ & $21.78 \pm 8.14^{c, d, e}$ & $>100$ \\
\hline
\end{tabular}

${ }^{a} \mathrm{IC}_{50}$ is defined as the concentration that reduces cell number by $50 \%$ compared with control cultures. The data represents the means \pm SD of the results from three independent experiments. Data are evaluated by two-tailed unpaired $t$-test. ${ }^{b}$ Cisplatin was used as a positive control. ${ }^{c} p<0.05$ as compared with the compound 1-treated group in the same cells. ${ }^{d} p<0.05$ as compared with the compound 2-treated group in the same cells. ${ }^{e} p<0.05$ as compared with the compound 3-treated group in the same cells. ${ }^{f} p<0.05$ as compared with the cisplatin-treated group in the same cells.

The other known compounds were identified as protodioscin (2) [10], methyl protodioscin (3) [15], aspacochioside A (4) [16], aspacochioside C (5) [16], 15-hydroxypseudoprotodioscin (6) [17], and chamaedroside E (7) [18] by comparison of their NMR spectroscopic data with those previously reported data.

\subsection{The Cytotoxicity of the Compounds Isolated from A. cochinchinensis against Human Ovarian} Cancer Cells

To evaluate the potential anti-tumor activity of the isolates from the hot water extract of $A$. cochinchinensis, the cytotoxicity of compounds 1-7 against human ovarian cancer cells (A2780 and SKOV3) were examined using a 3-[4,5-dimethylthiazol-2-yl]-2,5-diphenyl tetrazolium bromide (MTT) assay.

As shown in Table 3 and Figure 3, asparacochioside A (1), protodioscin (2), and methyl protodioscin (3) exhibited a significant cytotoxicity in A2780 cells with $\mathrm{IC}_{50}$ values of 5.25, 10.14 , and $21.78 \mu \mathrm{M}$, respectively, in a dose dependent manner. In SKOV3 cells, only the new compound asparacochioside A (1) showed a significant cytotoxicity with observed $\mathrm{IC}_{50}$ value of $46.82 \mu \mathrm{M}$, while compounds $4-7$ were not active against either A2780 or SKOV3 human ovarian cancer cells $(>100 \mu \mathrm{M})$. Overall, among the seven compounds isolated from $A$. cochinchinensis, only the novel compound $\mathbf{1}$ showed a potent cytotoxicity against both A2780 and SKOV3, suggesting its potential anti-cancer activity in human ovarian cancer.

Both protodioscin (2) and methyl protodioscin (3) have been reported to show various biological activities such as anti-tumor and anti-inflammatory effects $[19,20]$. However, this is the first study to demonstrate their cytotoxicity against human ovarian cancer cells. Protodioscin (2) showed more potent cytotoxicity against A2780 cells than methyl protodioscin (3), suggesting that the methylation at C-22 hydroxy group may interrupt the activity of protodioscin (3). Although asapacochioside C (5) was cytotoxic against human lung adenocarcinoma A549 cells [21], it failed to show a significant cytotoxicity against human ovarian cancer cells in this study. Reportedly, chamaedroside E (7) was first isolated from Veronica chamaedrys [18]. However, the presence of 7 in A. cochinchinensis was found in this study, for the first time. 
$\mathbf{A}$

B

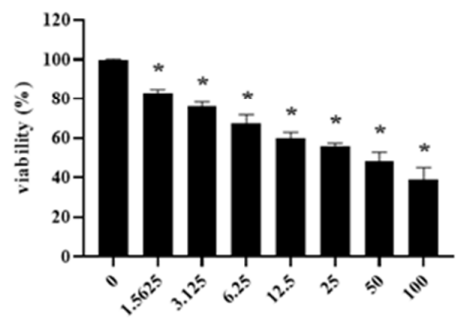

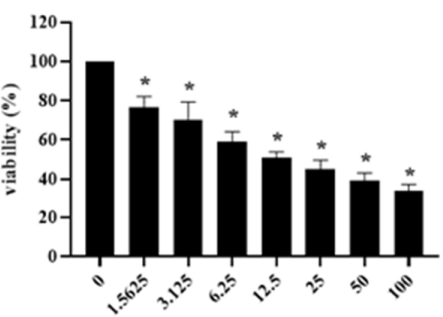

Compound $2(\mu \mathrm{M})$

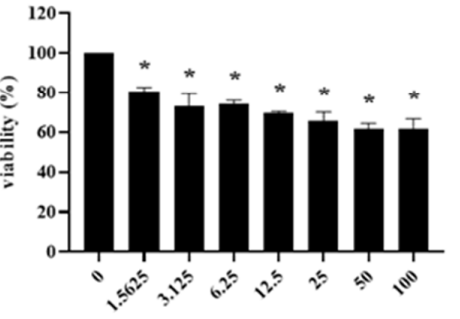

Compound $2(\mu \mathrm{M})$

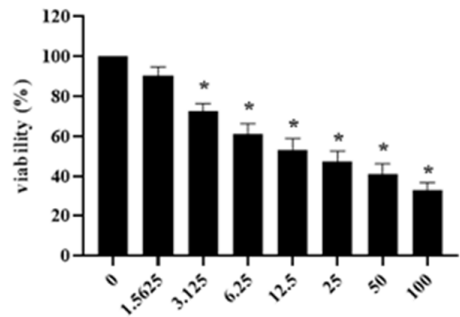

Compound $3(\mu \mathrm{M})$

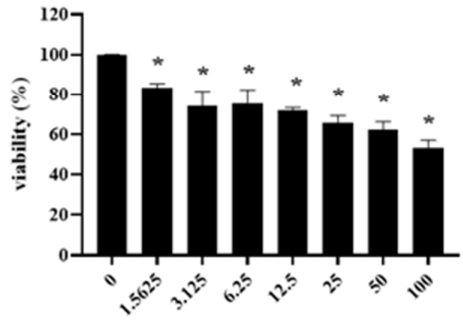

Compound $3(\mu \mathrm{M})$

Figure 3. The effects of compounds 1-3 on cell viability in human ovarian cancer cells A2780 (A) and SKOV3 (B). Ovarian cancer cells (A2780 and SKOV3) were treated with compounds 1-3 in the indicated concentrations for $48 \mathrm{~h}$. Data are presented as mean \pm SD and evaluated by one-way ANOVA analysis. ${ }^{*} p<0.05$ as compared with the untreated group.

\subsection{Induction of Apoptotic Cell Death by Asparacochioside A (1) in Human Ovarian Cancer Cells}

To further investigate whether the cytotoxicity of asparacochioside A (1) was associated with the induction of apoptosis, Annexin V-FITC staining was performed. Asparacochioside A (1) significantly increased the percentage of Annexin V positive cells (apoptotic cells) in a dose- and time-dependent manner (Figure 4). These results indicate that asparacochioside A-induced cytotoxicity was associated with apoptosis in human ovarian cancer cells.

A

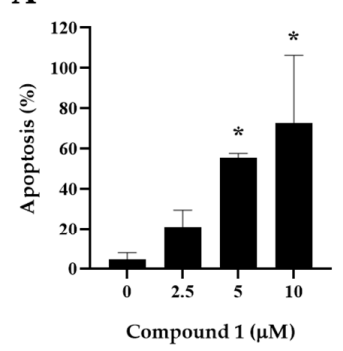

B

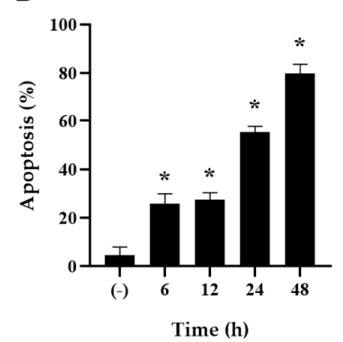

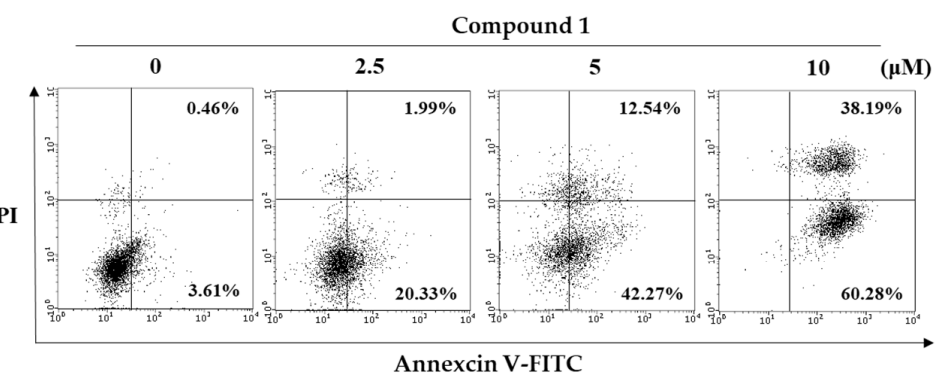

Compound 1

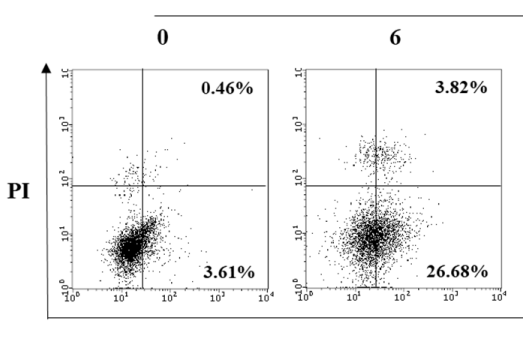

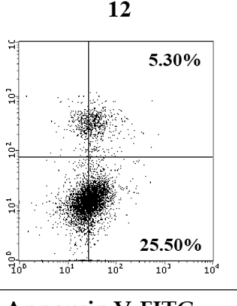

Annexcin V-FITC

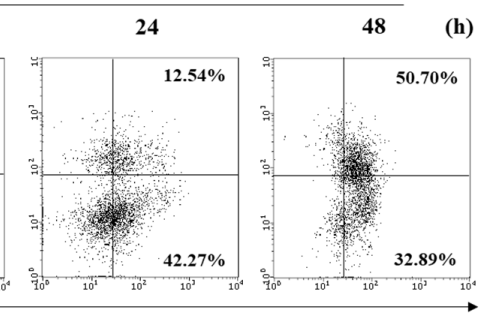

Figure 4. The effect of compound 1 on apoptosis in A2780 cells. Cells were treated with compound 1 for the indicated concentrations $(2.5,5.0$, and $10 \mu \mathrm{M})(\mathbf{A})$ and times $(6,12,24$, and $48 \mathrm{~h})(\mathbf{B})$, and then co-stained with propidium iodide (PI) and Annexin V-FITC. The graph indicates the percentage of apoptosis. Data are presented as mean \pm SD and evaluated by one-way ANOVA analysis. * $p<0.05$ as compared with control. 


\section{Materials and Methods}

\subsection{Plant Material}

The roots of Asparagus cochinchinensis (Loureio) Merrill (Liliaceae) were purchased from Nanuum pharmaceutical Co. (Youngcheon-si, Kyungsangbukdo, South Korea), in May 2017. The plant material was identified by D.S.J. and a voucher specimen (ASCO12017) has been deposited in the Lab. of Natural Product Medicine, Kyung Hee University.

\subsection{General Experimental Procedures}

General experimental procedures are provided in the Supplementary Materials.

\subsection{Isolation of Compounds $\mathbf{1}-\mathbf{7}$}

Dried roots of $A$. cochinchinensis $(800 \mathrm{~g})$ were extracted with distilled water $(8 \mathrm{~L})$ at $100{ }^{\circ} \mathrm{C}$ for $2 \mathrm{~h}$, and the solvent was removed using rotary evaporator. The extract (300.0 g) was subjected to Diaion HP column chromatography $(C C, 9.6 \times 56.0 \mathrm{~cm})$, eluting with $\mathrm{MeOH}-\mathrm{H}_{2} \mathrm{O}$ gradient system (from 0:1 to 1:0 $v / v$ ) to afford 12 fractions (C1 C12). Fraction C4 $(3.8 \mathrm{~g})$ was separated by Sephadex LH-20 CC $(4.3 \times 57.5 \mathrm{~cm})$ with acetone $-\mathrm{H}_{2} \mathrm{O}(4: 6 \mathrm{v} / \mathrm{v})$ to make four fractions $(\mathrm{C} 4-1 \sim \mathrm{C} 4-4)$. Fraction $\mathrm{C} 4-3(2.2 \mathrm{~g})$ was subjected further to silica gel CC $(3.3 \times 34.0 \mathrm{~cm}, 230-400$ mesh $)$ with EtOAc-acetone $-\mathrm{H}_{2} \mathrm{O}$ mixture $(3: 6: 1 \mathrm{v} / \mathrm{v} / \mathrm{v})$, yielding seven subfractions $(\mathrm{C} 4-3-1 \sim \mathrm{C} 4-3-7)$. Chamaedroside $\mathrm{E}(7,21.5 \mathrm{mg})$ was purified by HPLC with Gemini $5 \mu \mathrm{m}$ NX-C18 110A column (acetonitirle- $\mathrm{H}_{2} \mathrm{O}=25: 75$ to 40:60, $v / v)$ from subfraction C4-3-4 $(60.8 \mathrm{mg})$. Fraction $\mathrm{C} 6(12.0 \mathrm{~g})$ was loaded to a silica gel column (230-400 mesh; $5.6 \times 35.0 \mathrm{~cm})$ and eluted with $\mathrm{CH}_{2} \mathrm{Cl}_{2}-\mathrm{MeOH}-\mathrm{H}_{2} \mathrm{O}$ solvent system [14:6:1 $\mathrm{v} / \mathrm{v} / \mathrm{v}]$ to afford seven subfractions (C6-1 C6 -7$)$. Subfraction $\mathrm{C} 6-4(1.75 \mathrm{~g})$ was subjected to silica gel CC $\left(5.2 \times 25.5 \mathrm{~cm}, 230-400\right.$ mesh) with EtOAc-acetone- $\mathrm{H}_{2} \mathrm{O}$ mixture (from 4:5:1 to 0:8:2 $v / v / v$ ), yielding protodioscin $(2,217.8 \mathrm{mg}$ ). Subfraction C6-5 (7.16 g) was subjected to silica gel CC $(230-400 \mathrm{mesh} ; 5.2 \times 32.0 \mathrm{~cm})$ eluting with EtOAc-acetone $-\mathrm{H}_{2} \mathrm{O}$ [4:5:1 to 3.5:5:1.5 $\left.\mathrm{v} / \mathrm{v} / \mathrm{v}\right]$ and afforded methylprotodioscin $(3,1.56 \mathrm{~g})$. Aspacochioside A $(4,118.7 \mathrm{mg})$ was separated from subfraction C6-2 $(392.0 \mathrm{mg})$ by silica gel CC $(3.6 \times 26.0 \mathrm{~cm}, 230-400$ mesh $)$ with EtOAc-acetone $-\mathrm{H}_{2} \mathrm{O}$ mixture $(4: 5: 1 \mathrm{v} / \mathrm{v} / \mathrm{v})$. Subfraction C6-6 $(2.11 \mathrm{~g})$ was fractionated by silica gel CC $(230-400 \mathrm{mesh} ; 4.4 \times 30.0 \mathrm{~cm})$, eluting with EtOAc-acetone $-\mathrm{H}_{2} \mathrm{O}$ gradient system [from 4:5:1 to 3.5:5:1.5 $v / v / v$ ] to yield compound 1 (724.2 $\mathrm{mg})$.

Fraction C7 $(16.3 \mathrm{~g})$ was subjected to silica gel CC $(5.8 \times 40.0 \mathrm{~cm}, 230-400$ mesh) with EtOAc-acetone $-\mathrm{H}_{2} \mathrm{O}$ mixture $(4: 5: 1 v / v / v)$ to generate nine subfractions $(\mathrm{C} 7-1 \sim \mathrm{C} 7-9)$. $15-$ Hydroxy-pseudoprotodioscin $(6,211.0 \mathrm{mg})$ was purified by flash chromatography using a Redi Sep-C18 cartridge ( $130 \mathrm{~g}$, acetonitrile $-\mathrm{H}_{2} \mathrm{O}$, from 15:85 to 40:60 $\mathrm{v} / \mathrm{v}$ ) from C7-6 (1.6 g). Protodioscin (2, $2.08 \mathrm{~g}$ was obtained additionally from subfraction C7 -8 $(9.7 \mathrm{~g})$ by flash chromatography using a Redi Sep-C18 cartridge $\left(130 \mathrm{~g}\right.$, acetonitrile $-\mathrm{H}_{2} \mathrm{O}$, from 15:85 to $45: 55 v / v)$.

Fraction C9 (406.6 mg) was fractionated further by flash chromatography using a Redi Sep-C18 cartridge (130 g, acetonitrile- $\mathrm{H}_{2} \mathrm{O}$, from 10:90 to 40:60 v/v) to afford aspacochioside C $(5,68.6 \mathrm{mg})$.

Asparacochioside A (1)

Pale brown powder; m.p.: $188.2^{\circ} \mathrm{C} ;[\alpha]_{\mathrm{D}}^{20}:-63^{\circ}($ c $0.1, \mathrm{MeOH})$; IR (ATR) vmax 3410, $1745,1712 \mathrm{~cm}^{-1} ; \mathrm{HR}-\mathrm{Q}-\mathrm{TOF}-\mathrm{MS}$ (negative mode) $\mathrm{m} / z=1209.5892[\mathrm{M}-\mathrm{H}]^{-}$, (calcd for C57H93O27, 1209.5904); ${ }^{1} \mathrm{H}$ - and ${ }^{13} \mathrm{C}-\mathrm{NMR}$ data, see Tables 1 and 2.

\subsection{Acidic Hydrolysis of Compound $\mathbf{1}$}

Compound $1(10.0 \mathrm{mg})$ was hydrolyzed with $1 \mathrm{~N} \mathrm{HCl}$ at $80{ }^{\circ} \mathrm{C}$ for $3 \mathrm{~h}$. Sodium bicarbonate was added to stop the reaction. 


\subsection{Absolute Configurations of the $\beta$-Glucose and $\alpha$-Rhamnose in Compound 1}

The absolute configurations of $\beta$-glucose and $\alpha$-rhamnose in $\mathbf{1}$ was determined using the method reported by Tanaka et al. [21]. The hydrolysate was derivatized with pyridine $(500 \mu \mathrm{L}), \mathrm{L}$-cysteine methyl ester hydrochloride $(1.2 \mathrm{mg})$, and $\sigma$-tolyl isothiocyanate $(100 \mu \mathrm{L})$ and analyzed using HPLC. The glucose and rhamnose in the reaction mixture of $\mathbf{1}$ was detected at 30.7 and $35.5 \mathrm{~min}$, respectively. The retention times of authentic D-glucoses and L-rhamnose were 30.8 and $35.4 \mathrm{~min}$, respectively, under the same HPLC conditions. Therefore, the absolute configuration of $\beta$-glucose in $\mathbf{1}$ was confirmed as the D configuration, whereas $\alpha$-rhamnose was confirmed as the L configuration.

\subsection{Cell Culture}

A2780 and SKOV3 human ovarian cancer cell lines were obtained from American Type Culture Collection (ATCC). The cells were maintained in Roswell Park Memorial Institute (RPMI) 1640 (Life Technologies Inc., Grand Island, NY, USA) medium with penicillin (100 U/mL), 5\% fetal bovine serum (FBS), and streptomycin sulfate $(100 \mu \mathrm{g} / \mathrm{mL}$, Life Technologies Inc.). Cells with medium were kept in humidified atmosphere of $5 \% \mathrm{CO}$ and $37^{\circ} \mathrm{C}$ temperatures.

\subsection{MTT Assay}

The cell growth was assessed using the MTT assay. Briefly, Cells were seeded in a 96-well plate at a density of $1 \times 10^{5} / \mathrm{mL}$ per well. After $24 \mathrm{~h}$, cells were treated with different concentrations of extract or compounds for $48 \mathrm{~h}$. Following incubation, $50 \mu \mathrm{L}$ of MTT ( $1 \mathrm{mg} / \mathrm{mL}$ stock solution, molecular probes Inc., Eugene, OR, USA) was added and incubated for $4 \mathrm{~h}$ in the $37^{\circ} \mathrm{C}$ incubator. The medium was discarded and the formazan crystals were dissolved in DMSO. The absorbance was measured using a microplate spectrophotometer (SpectraMax; Molecular Devices, Sunnyvale, CA, USA) at $540 \mathrm{~nm}$.

\subsection{Annexin V-FITC Staining Assay for Apoptosis Analysis}

Apoptotic cells were detected by the binding of fluorescent Annexin V (Annexin V-FITC). Cells were treated with asparacochioside A (1) for indicated time periods or concentrations. After incubation, both floating and adherent cells from each well collected in tubes and washed with PBS. The cells were then re-suspended in $500 \mu \mathrm{L}$ of binding buffer and stained with $2.75 \mu \mathrm{L}$ of FITC-conjugated Annexin V for $15 \mathrm{~min}$ in darkness. Finally the stained cells were washed with binding buffer and stained with $5 \mu \mathrm{L}$ of PI $\left(50 \mathrm{mg} / \mathrm{mL}\right.$ ) prior to analysis using a Guava ${ }^{\circledR}$ easyCyte flow cytometer (Merck Millipore, Burlington, MA, USA).

\subsection{Statistical Analysis}

All statistical parameters were calculated using GraphPad Prism 5.0 (GraphPad Software, Inc., La Jolla, CA, USA). Data are presented as mean \pm SD and evaluated by unpaired Student $t$-test or one-way ANOVA analysis. Difference with a $p$-value less than 0.05 was considered to be statistically significant.

\section{Conclusions}

Seven compounds 1-7, including a new furostane-type steroidal saponin named asparacochioside A (1) were isolated from the roots of A. cochinchinensis in the present study. The chemical structure of the new compound was determined using their spectroscopic data $\left({ }^{1} \mathrm{H}-\mathrm{NMR},{ }^{13} \mathrm{C}-\mathrm{NMR}, \mathrm{DEPT}, \mathrm{HSQC}, \mathrm{HMBC}, \mathrm{NOESY}\right.$, and HR-Q-TOF-MS) measurement and by acidic hydrolysis. Isolation of chamaedroside $\mathrm{E}(7)$ from the roots of A. cochinchinensis was reported for the first time in this paper. Among the isolates, asparacochioside A (1), protodioscin (2), and methyl protodioscin (3) exhibited a significant cytotoxicity against A2780 cells. In SKOV3 cells, only the new compound asparacochioside A (1) showed a significant cytotoxicity. Compound $\mathbf{1}$ induced apoptotic cell death in human ovarian cancer cells and significantly increased the percentage of annexin $\mathrm{V}$ positive cells 
(apoptotic cells) in a dose- and time-dependent manner. Thus, asparacochioside A (1) is worthy of additional experiments for its potential as an anti-cancer agent.

Supplementary Materials: The following are available online at https:/ /www.mdpi.com/article/10 .3390 / plants10102067/s1, General Experimental Procedure, The HR-ESI-MS, ${ }^{1} \mathrm{H}-\mathrm{NMR}(800 \mathrm{MHz}$, $\left.\mathrm{C}_{5} \mathrm{D}_{5} \mathrm{~N}\right),{ }^{13} \mathrm{C}-\mathrm{NMR}\left(200 \mathrm{MHz}, \mathrm{C}_{5} \mathrm{D}_{5} \mathrm{~N}\right)$, DEPT135-NMR, HSQC, COSY, HMBC, and NOESY spectra of 1 (Figures S1-S7).

Author Contributions: Conceptualization, J.-H.C. and D.S.J.; Funding acquisition, D.S.J.; Investigation, J.-Y.K., H.Y.C., H.M.K.; Supervision, J.-H.C. and D.S.J.; Writing-original draft, J.-Y.K. and H.Y.C.; Writing-review \& editing, J.-H.C. and D.S.J. All authors have read and agreed to the published version of the manuscript.

Funding: This work was supported by Korea Institute of Planning and Evaluation for Technology in Food, Agriculture and Forestry (IPET) funded by Ministry of Agriculture, Food and Rural Affairs (MAFRA) (grant number: P430-117010-1) and by a grant from the National Research Foundation of Korea (NRF) funded by the Ministry of Science and ICT (MSIT), Republic of Korea (grant number: NRF-2019R1A2C1083945).

Institutional Review Board Statement: Not applicable.

Informed Consent Statement: Not applicable.

Conflicts of Interest: The authors declare no conflict of interest.

\section{References}

1. Negi, J.S.; Singh, P.; Joshi, G.P.; Rawat, M.S.; Bisht, V.K. Chemical constituents of Asparagus. Phamacogn. Rev. 2010, 4, 215-220.

2. Xiong, D.; Yu, L.X.; Yan, X.; Guo, C.; Xiong, Y. Effects of root and stem extracts of Asparagus cochinchinensis on biochemical indicators related to aging in the brain and liver of mice. Am. J. Chin. Med. 2011, 39, 719-726. [CrossRef]

3. Shen, Y.; Xu, C.L.; Xuan, W.D.; Li, H.L.; Liu, R.H.; Xu, X.K.; Chen, H.S. A new furostanol saponin from Asparagus cochinchinensis. Arch. Pharm. Res. 2011, 34, 1587-1591. [CrossRef]

4. Guo-Lei, Z.H.U.; Qian, H.A.O.; Rong-Tao, L.I.; Hai-Zhou, L.I. Steroidal saponins from the roots of Asparagus cochinchinensis. Chin. J. Nat. Med. 2014, 12, 213-217.

5. Le Son, H.; Anh, N.P. Phytochemical composition, in vitro antioxidant and anticancer activities of quercetin from methanol extract of Asparagus cochinchinensis (Lour.) Merr. tuber. J. Med. Plant. Res. 2013, 7, 3360-3366.

6. Samad, N.B.; Debnath, T.; Abul Hasnat, M.; Pervin, M.; Kim, D.H.; Jo, J.E.; Park, S.R.; Lim, B.O. Phenolic Contents, Antioxidant and Anti-inflammatory Activities of Asparagus cochinchinensis (Loureiro) Merrill. J. Food Biochem. 2014, 38, 83-91. [CrossRef]

7. Park, M.; Cheon, M.S.; Kim, S.H.; Chun, J.M.; Lee, A.Y.; Moon, B.C.; Yoon, T.; Choo, B.K.; Kim, H.K. Anticancer activity of Asparagus cochinchinensis extract and fractions in HepG2 cells. J. Korean Soc. Appl. Bio Chem. 2011, 54, 188-193. [CrossRef]

8. Zhou, M.; Huang, L.; Li, L.; Wei, Y.; Shu, J.; Liu, X.; Huang, H. New furostanol saponins with anti-inflammatory and cytotoxic activities from the rhizomes of Smilax davidiana. Steroids 2017, 127, 62-68. [CrossRef] [PubMed]

9. Tang, C.; Yu, Y.M.; Qi, Q.L.; Wu, X.D.; Wang, J.; Tang, S.A. Steroidal saponins from the rhizome of Polygonatum sibiricum. J. Asian. Nat. Prod. Res. 2019, 21, 197-206. [CrossRef] [PubMed]

10. Hu, K.; Dong, A.; Yao, X.; Kobayashi, H.; Iwasaki, S. Antineoplastic agents II: Four furostanol glycosides from rhizomes of Dioscorea collettii var. hypoglauca. Planta Med. 1997, 63, 161-165. [CrossRef] [PubMed]

11. Zhu, G.L.; Hao, Q.; Xing, L.; Yang, X.Q.; Xie, S.D.; Zhao, P.; Li, H.Z. C $21, C_{22}$ pregnane glycosides and cytotoxic $C_{27}$ spriostanol steroids from Asparagus cochinchinesis. Steroids 2021, 172, 108874. [CrossRef]

12. Singh, S.B.; Thakur, R.S. Costusoside-I and costusoside-J, two new furostanol saponins from the seeds of Costus speciosus. Phytochemistry 1982, 21, 911-915. [CrossRef]

13. Agrawal, P.K. Dependence of ${ }^{1} \mathrm{H}$ NMR chemical shifts of geminal protons of glycosyloxy methylene $\left(\mathrm{H}_{2}-26\right)$ on the orientation of the 27-methyl group of furostane-type steroidal saponins. Magn. Reson. Chem. 2004, 42, 990-993. [CrossRef]

14. Challinor, V.L.; Piacente, S.; De Voss, J.J. NMR assignment of the absolute configuration of C-25 in furostanol steroidal saponins. Steroids 2012, 77, 602-608. [CrossRef]

15. Ju, Y.; Jia, Z.J. Steroidal saponins from the rhizomes of Smilax menispermoidea. Phytochemistry 1992, 31, 1349-1351. [CrossRef]

16. Shi, J.G.; Li, G.Q.; Huang, S.Y.; Mo, S.Y.; Wang, Y.; Yang, Y.C.; Hu, W.Y. Furostanol oligoglycosides from Asparagus cochinchinensis. J. Asian Nat. Prod. Res. 2004, 6, 99-105. [CrossRef] [PubMed]

17. Huang, H.L.; Liu, R.H.; Shao, F. Structural determination of two new steroidal saponins from Smilax china. Magn. Reson. Chem. 2009, 47, 741-745. [CrossRef] [PubMed]

18. Marchenko, A.; Kintya, P.; Wyrzykiewicz, B.; Gorincioi, E. Steroidal glycosides from Veronica chamaedrys L. Part I. The structures of chamaedrosides C, C1, C2, E, E1 and E2. Nat. Prod. Commun. 2012, 7, 565-568. [CrossRef] [PubMed] 
19. Podolak, I.; Galanty, A.; Sobolewska, D. Saponins as cytotoxic agents: A review. Phytochem. Rev. 2010, 9, 425-474. [CrossRef] [PubMed]

20. Sautour, M.; Mitaine-Offer, A.C.; Lacaille-Dubois, M.A. The Dioscorea genus: A review of bioactive steroid saponins. J. Nat. Med. 2007, 61, 91-101. [CrossRef]

21. Tanaka, T.; Tatsuya, N.; Toshihisa, U.; Kenji, T.; Isao, K. Facile discrimination of aldose enantiomers by reversed-phase HPLC. Chem. Pharm. Bull. 2007, 55, 899-901. [CrossRef] [PubMed] 